\title{
Assessing the Impact of Interest Rate on Foreign Exchange Rate in Ghana
}

\author{
Dickson Akoto \\ Radford Business School, Radford University College, Accra, Ghana \\ Email address: \\ dickakoto2003@yahoo.com \\ To cite this article: \\ Dickson Akoto. Assessing the Impact of Interest Rate on Foreign Exchange Rate in Ghana. International Journal of Accounting, Finance \\ and Risk Management. Vol. 5, No. 4, 2020, pp. 184-190. doi: 10.11648/j.ijafrm.20200504.12
}

Received: September 7, 2020; Accepted: October 23, 2020; Published: November 19, 2020

\begin{abstract}
Foreign exchange rates determine the strength of a nation's currency against other nation's currency. Determination of foreign exchange rates in Ghana is therefore, of immense importance since the livelihood of many people in the country is tied to the performance of the local currency against the foreign currencies. Data from books and journals were used as the basis for the research; the research result was then compared to the work of earlier writers to ascertain the conformity or otherwise of the Ghanaian situation. The research involved comparing the percentage changes in interest rates of commercial banks in Ghana to the percentage changes in exchange rates for the period 2008 to 2018 to ascertain the relationship between the two variables. Quantitative research design was used for the work. The researcher determined the mean and standard deviation of the distribution and computed the coefficient of correlation for the variables and in addition the regression analysis. The coefficient of correlation was -0.5 and the gradient of the regression line was also -.05 . The research showed that interest rates were strongly negatively related to the exchange rates in Ghana for the period 2008 to 2018 . This explained why exchange rates in Ghana kept falling while interest rates rose continuously which is contrary to postulates that indicate, a rise in interest rates results in rise in exchange rates. The researcher noted that the great disparity between the lending rate and deposit rate in Ghana is a contributing factor to this anomaly.
\end{abstract}

Keywords: Foreign Exchange Rate, Interest Rate, Purchasing Power Parity, Cost of Capital

\section{Introduction}

Foreign exchange operations in Ghana have been of much concern to many people, especially after the country changed its foreign exchange policy from fixed exchange rates to flexible exchange rates. Ghana is predominantly net importer of goods and services, hence movements in the foreign exchange rates determine much of the country's economic activities. The country has experienced falling exchange rates for decades. The state in a bid to perhaps, reduce the constant fall of the currency decided to artificially peg the dollar to the local currency, the cedi, at $\$ 1$ to 1 cedi on $1^{\text {st }}$ July 2007 . This situation did not last, since many factors accounted for the value of a currency. As at the time of writing this article the dollar is worth GHc 5.6, a fall in exchange rate of $460 \%$ over the period.

Some of the key determinants of a country's exchange rate is the volume of exports and the country's interest rate. The researcher acknowledging the fact that the country is already a net importer of goods and services realised that exports have little effect on Ghana's exchange rates. He therefore, resolved to assess the impact of interest rates on the foreign exchange rate in Ghana. This research will assist policy makers to make decisions on the country's interest rates that will ensure desirable exchange rate for the nation's currency and improve the lives of its people.

\section{Literature Review}

\subsection{Foreign Exchange and Exchange Rate}

According to Walstand and Bingham [1] foreign exchange is when residents of a nation sell goods or services or real or financial assets to receive loans or gifts or from, or are paid dividends or interest by the residents of foreign nations and obtain foreign money and sell this foreign money in return for some of their own money. That is, they exchange foreign money for their own money. 
According to Gordon, the foreign exchange for a nation's currency is the amount of one nation's money that can be obtained in exchange for a unit of another nation's money. According to McEachern, foreign exchange is the currency of another country needed to carry out international transactions. The exchange rate is the price measured in one's currency of purchasing 1 unit of another country's currency $[2,3]$.

\subsection{Flexible Vr Fixed Exchange Rates}

According to Gordon [2] flexible exchange rate systemUnder a 'pure' version of the flexible exchange rate system, an outflow of a currency would act just like an excess supply of any commodity, the price would go down until an equilibrium price is established. In a flexible exchange rate system, the foreign exchange rate is free to change every day in order to establish an equilibrium between the quantities supplied and demanded of a nation's currency. In a fixed exchange rate system, the foreign exchange rate is fixed for long periods.

McEachern [3] defines flexible exchange rate as rate determined by the forces of demand and supply without government intervention. According to him fixed exchange rate is the rate of exchange between currencies pegged within a narrow range and maintained by the central bank's ongoing purchases and sales of currencies.

\subsection{Nominal Exchange Rate and Real Exchange Rate}

According to Abel and Bernanke [4] the rate at which two currencies can be traded is the nominal exchange rate between the two currencies. When the exchange rate falls so that, a dollar buys fewer units of foreign currency, the dollar is said to undergo a nominal depreciation. This implies that the dollar has become 'weaker'. However, if the dollar's nominal exchange rate rises, then the dollar has had a nominal appreciation. This implies that the dollar has become 'stronger'.

According to them, the price of domestic goods relative to foreign goods-equivalently, the number of foreign goods someone gets in exchange for one domestic good is called the real exchange rate.

\subsection{Purchasing Power Parity}

According to Taylor and Taylor [5] Purchasing power parity (PPP) is a disarmingly simple theory that holds that the nominal exchange rate between two currencies should be equal to the ratio of aggregate price levels between the two countries, so that a unit of currency of one country will have the same purchasing power in a foreign country.

According to Kargbo [6], his research shows overwhelming support for long-run PPP in Africa, thus, PPP is a reliable guide for exchange rate determination and exchange rate policy reform in African countries.

According to Suluk, S and Tannseven, K [7], if domestic inflation is bigger than international inflation, local currency will weaken in the long run. If domestic inflation is smaller than international inflation then it will be reflected in a corresponding strengthening of the local currency in the long run.

\subsection{Factors that Influence Exchange Rates}

According to Stafford [8], as a general rule, the currencies of countries that pay higher interest rates tend to be in demand and therefore do appreciate, while the currencies of countries that pay lower interest rates tend to be demanded less and therefore depreciate. He also asserts that people and businesses usually invest their money in countries that have expanding economic systems. Another factor is expectations; if many people believed that the value of a currency would soon increase, they would sell their local currency and buy the other currency. The result is that the value of the foreign currency would appreciate and the value of the local currency would depreciate.

Hubbard and O'brien [9] also opine that three main factors that cause the supply and demand curves in the foreign exchange market to shift are changes in the demand for a country's produced goods and services; changes in the expectations of currency traders- particularly speculators concerning the values of the local currency and the likely future values of foreign currencies; changes in the desire to invest in the domestic currency and changes in the desire to invest in foreign currency. According to Khan [10] monetary policy uses the interest rate and targets the domestic and CPI inflation to control the exchange rate.

\subsection{Interest Rates}

According to Gordon [2], interest rates help the economy allocate saving among alternative uses. For savers, the interest rate is a reward for abstaining from consumption and waiting to consume at some future time. The higher the interest rate the greater the incentive to save. For borrowers, the interest rate is the cost of borrowing funds to invest or buy consumption goods. Thus, if the desire to borrow exceeds the willingness to save sufficient funds, the interest rate tends to rise.

According to Kartal [11] Interest rates are important for economies because their changes may result in either negative or positive effects on economic actors, and also they are indicators to make decisions on investments of companies and institutions by setting the level of the cost of money.

\subsection{Determinants of Interest Rates}

According to Tumwine et al [12] liquidity, equity capital, market power and reserve requirement have a positive effect on interest rate.

Other determinants of interest rate include Real Risk-Free Rate and Default risk Premiums. The risk free rate of return is taken into consideration when the lender takes into account the return he would receive if he invested his funds in instruments that bear no risk.

Default-Risk Premium; this is when the lender takes into account the chance that the borrower won't make payments 
on time, or will not be able to repay when the funds are advanced to him. The premium charged on the credit facility will be high or low depending on the creditworthiness of the borrower.

\subsection{The Determination of Short-Term Interest Rates Are as Follows}

Monetary policy instruments; the standard mode; differing policy objective; transmission mechanisms; globalisation and the exchange rate according to Economic Affairs Series [13]. The Determination of Long-term Interest Rates are as follows Short-term Rates and Inflationary Expectations; real expectations: evidence from index-linked bonds; international markets and exchange rates; public sector borrowing.

With the growth of "big government" over the last century, the level and financing of public expenditure has become an increasingly important influence on long-term interest rates. In many economies the available traded bonds have been overwhelmingly "sovereign debt" — that is, borrowing by governments to fund budget deficits. In such economies, fiscal policy has, therefore, been as important an interest rate determinant as monetary policy.

\subsection{Price/Yield Levels of Other Assets}

It has been observed that there are complex interactions between bond prices and equity prices. Though equity yields will normally be below bond yields - reflecting the expectation of capital appreciation - a rising equity market can be associated with either rising or falling bond markets, depending upon the underlying causes.

Long-term interest rates will therefore also reflect the expectations of investors in equities - and, indeed, all the other markets. i.e. commodities, real estate, antiques, derivatives, and so on.

"In an environment of improving expectations for economic activity in the euro area, the principal explanation for the volatility in euro area stock prices seemed to have been a spillover of declines in stock prices in the United States. In addition, the aforementioned upward movements in domestic long-term bond yields may have placed a downward pressure on stock prices."

\subsection{Long-Term Rates, Demand and Growth; and Cost of Capital}

The economic forces which determine long-term interest rates are therefore highly complex. Is it nevertheless true despite uncertainties about the transmission mechanisms that movements in long-term rates will have a predictable effect on the real economy? The classical economic model, asserts that rising interest rates will cause the cost of capital to rise, and hence cause investment to fall. This, in turn, will cause a fall in aggregate demand and output. Similarly, a fall in long-term rates should result in increased investment, demand and output.

Empirical research does, in general, confirm the theory. A study carried out by Thomas Meyer of Goldman Sachs (1999), showed that a steeper yield curve depressed credit demand, leading to a reduction in GDP growth of around $0.75 \%$ for every $1 \%$ rise in rates after a time lag of a few quarters. However, it does not automatically follow that a fall in long-term rates will have a similarly positive effect on growth. Recent experience in Japan also shows that even if long rates are low - they have fluctuated between 1 and $2 \%$ during 1998 and 1999 — the boost to the real economy has been minimal.

Much also depends on the structure of an economy, and the components of demand. Interest rate changes feed through at varying speeds to different sectors, with different effects on asset prices. The effect on inventories is more immediate than on capital projects. There can be strong regional variations, reflecting the structure of regional economies. In any case, it is methodologically difficult to disentangle the economic effects of changes in interest rates with those resulting from often associated changes: most notably, of fiscal policy.

At the macro level, for example, the orientations of fiscal and monetary policy may be in the same direction. But it is also possible for a "tight" monetary policy to be combined with a "lax" fiscal policy, and vice versa. At the micro level, the effects of an interest-rate rise on particular sectors can be offset by state aids or tax breaks. All that can be said for certain, therefore, is that long-term interest rates tend to move in step with movements in the real economy. Which cause and which effect, however, is not at all certain, according to Economic Affairs Series [13].

According to Kanwal et al [14]. Interest rate means any rate a lender charges, as a percentage of the principal, to anyone who borrows or use an asset. Interest rates are normally calculated on annual basis known as the annual percentage rate (APR).

According to the Association of Chartered Certified Accountants', Financial Strategy manual [15], the cost of capital includes 3 elements. These are as follows: The risk free rate of return - this is the return which would be required from an investment, if it were completely free from risk. Eg Government treasury bills. The premium for business risk this is an increase in the required rate of return due to the existence of uncertainty about the future and about a firms business prospects. Business risks will be higher for some firms than for others. The premium for financial risk - this relates to the danger of high debt levels (high gearing). For ordinary shareholders, financial risk is evident in the variability of earnings after deducting payments to holders of debt capital. The higher the gearing of a company's capital structure, the greater will be the financial risk to ordinary shareholders, and this should be reflected in a higher risk premium, therefore, higher cost of capital because different companies are in different types of businesses (varying business risk and have different capital structures (varying financial risk) the cost of capital applied to one company may differ radically from the cost of capital of another.

According to Amlani [16], in his article in the Accounting 
and Business magazine of the Association of Chartered Certified Accountants (ACCA), Sub Saharan Africa has some of the highest interest rates in the world according to a study in 2015 by Investmentfrontier.com. Three of the six countries with the world's highest interest rates are in Sub Saharan Africa. The three are Malawi, Gambia and Ghana. Interest rates in Sub Saharan Africa are commonly above 20\% a year for borrowers, and the spread between lending and borrowing rates is also extremely high $(8 \%-10 \%)$ compared with spreads in other regions of the world.

\section{Methodology}

Data for the research was obtained mainly from secondary sources such as data from the Ghana Statistical Service, Bank of Ghana, and other journals. The researcher considered the average interest rates of commercial banks in Ghana and the exchange rates over the period under consideration. The researcher used the United States dollar as the foreign currency for the exchange rate computation, this is because Ghana's Gross Domestic Product is measured in US dollars and moreover, this is the main foreign currency traded in the country. The research design for the project is quantitative method and comprises tables depicting the interest rates and the foreign exchange rates of Ghana within the survey period.

\subsection{Dependent Variable}

The foreign exchange rate over the period was considered the dependent variable.

\subsection{Independent Variable}

The interest rates over the survey period was considered the independent variable. Changes in interest rates were compared to changes in foreign exchange rate to establish the relationship between these two variables. The researcher also did a correlation analysis by computing the coefficient of correlation between changes in interest rates and changes in the exchange rates. This enabled the researcher to deduce whether relationship between changes in Ghana's interest rates and exchange rates was positive or negative. The researcher also computed the regression analysis of these variables to ascertain the relationship between the two variables by analysing the regression line; the nature of its gradient and the constant figure.

\section{Results and Findings}

In table 1 , in 2008, the percentage change in interest rate was 9.1 and the corresponding change in exchange rate was (17.3). In 2009, the percentage change in interest rate was 35.4 and the percentage change in exchange rate was (22.0).
In 2010, the percentage change in interest rate was (1.5) and the percentage change in exchange rate was 0 . In 2011, the percentage change in interest rate was (15.6) and the percentage change in exchange rate was (5.6). In 2012, the percentage change in interest rate was (5.6) and percentage change in exchange rate was (16.4). In 2013, the percentage change in interest rate was 1.9 and the percentage change in interest rate was (10.7). In 2014, the percentage change in interest rate was 23.1 and the percentage change in exchange rate was (32). In 2015, the percentage change in interest rate was 15.6 and the percentage change in exchange rate was (20.6). In 2016, the percentage change in interest rate was (2.7) and the percentage change in exchange rate was (3.7). In 2017 , the percentage change in interest rate was (2.8) and the percentage change in exchange rate was (3.8). In 2018, the percentage change in interest rate was (2.9) and the percentage change in exchange rate was (12).

In table 2, the mean of the percentage change in interest rates for the period was 4.9 and the standard deviation was 14.0. The mean of the percentage change in exchange rate for the period was (13.1) and the standard deviation was 26.20. The standard deviations for both variables show that the data distributions are normal.

The coefficient of correlation was -0.5 and the gradient of the regression line was also -0.5 . This analyses indicated that interest rates and exchange rates in Ghana over the period under consideration were strongly negatively correlated. Instead of the interest rate being positively related to the exchange rate it was rather negatively related in Ghana, hence the constant fall of the exchange rate despite the consistent rise in the interest rate.

The fact is that the interest rate gap in Ghana is big, i.e., the difference between the interest rates on deposits and lending is very high for example in certain banks when the lending rate is $34 \%$ the deposit rate is as low as $8 \%$. This is not conducive enough to attract investors to deposit their funds in the country and cause the local currency to increase in value against the foreign currency.

The regression equation also shows a negative constant figure of 18. This indicates the enormity of the consistent fall of the local currency, the cedi against the dollar over the period.

In 2009 and 2014 percentage change in interest rates were among the highest while the corresponding percentage change in exchange rates were among the lowest. The lowest percentage change in interest rates was in 2011 and the corresponding change in exchange rate was one of the highest. This shows that when the percentage change in interest rate is high the percentage change in exchange rate is low and vice versa.

Table 1. Comparing percentage change in interest rates to percentage change in exchange rates.

\begin{tabular}{|c|c|c|c|c|}
\hline YEAR & Interest Rates & $\%$ Change in interest rates & Exchange rates dollar equivalent of 1 cedi & \% change in Exchange Rates \\
\hline 2007 & 22 & & 1.1 & \\
\hline 2008 & 28 & 9.1 & 0.91 & $(17.3)$ \\
\hline 2009 & 32.5 & 35.4 & 0.71 & $(22.0)$ \\
\hline
\end{tabular}




\begin{tabular}{lllll}
\hline YEAR & Interest Rates & \% Change in interest rates & Exchange rates dollar equivalent of 1 cedi & \% change in Exchange Rates \\
\hline 2010 & 32 & $(1.5)$ & 0.71 & 0 \\
2011 & 27 & $(15.6)$ & 0.67 & $(5.6)$ \\
2012 & 25.5 & $(5.6)$ & 0.56 & $(16.4)$ \\
2013 & 26 & 1.9 & 0.5 & $(10.7)$ \\
2014 & 32 & 23.1 & 0.34 & $(32)$ \\
2015 & 37 & 15.6 & 0.27 & $(20.6)$ \\
2016 & 36 & $(2.7)$ & 0.26 & $(3.7)$ \\
2017 & 35 & $(2.8)$ & 0.25 & $(3.8)$ \\
2018 & 34 & $(2.9)$ & 0.22 & $(12)$ \\
\hline
\end{tabular}

Data on Interest Rates: Ghana Statistical Service [17].

Data on exchange rates: Bank of Ghana [18].

Table 2. Computation of deviations from the mean.

\begin{tabular}{lllll}
\hline YEAR & \% Change in interest rates & Deviation from mean & \% Change in exchange rates & Deviation from mean \\
\hline 2008 & 9.1 & 4.2 & $(17.3)$ & 4.2 \\
2009 & 35.4 & 30.5 & $(22)$ & 8.9 \\
2010 & $(1.5)$ & $(6.4)$ & 0 & 13.1 \\
2011 & $(15.6)$ & 20.5 & $(5.6)$ & $(7.5)$ \\
2012 & $(5.6)$ & $(10.5)$ & $(16.4)$ & 3.3 \\
2013 & 1.9 & $(3.0)$ & $(10.7)$ & $(2.4)$ \\
2014 & 23.1 & 18.2 & $(32)$ & 18.9 \\
2015 & 15.6 & 10.7 & $(20.6)$ & $(9.4)$ \\
2016 & $(2.7)$ & $(7.6)$ & $(3.7)$ & $(9.3)$ \\
2017 & $(2.8)$ & $(7.7)$ & $(3.8)$ & $(1.1)$ \\
2018 & $(2.9)$ & $(7.8)$ & $(12)$ & \\
\hline
\end{tabular}

Table 3. Correlation analysis of the results.

\begin{tabular}{|c|c|c|c|c|c|c|}
\hline$\%$ Change in interest rates & $\%$ Change in exchange rates & $U_{i}=$ & $V_{i}=$ & \multirow{2}{*}{$u_{i} v_{i}$} & \multirow{2}{*}{$U_{i}^{2}$} & \multirow{2}{*}{$V_{i}^{2}$} \\
\hline$\left(\mathbf{x}_{\mathbf{i}}\right)$ & $\left(\mathbf{y}_{\mathbf{i}}\right)$ & $X_{i}-4.9$ & $Y_{i}-(13.1)$ & & & \\
\hline 9.1 & -17.3 & 4.2 & 4.2 & 17.64 & 17.64 & 17.64 \\
\hline 35.4 & -22 & 30.5 & -35.1 & $-1,070.60$ & 930.25 & 1,232 \\
\hline-1.5 & 0 & -6.4 & -13.1 & 83.84 & 40.96 & 171.61 \\
\hline-15.6 & -5.6 & -20.5 & -18.7 & 383.35 & 420.25 & 349.69 \\
\hline-5.6 & -16.4 & -10.5 & -29.5 & 309.75 & 110.25 & 870.25 \\
\hline 1.9 & -10.7 & -3 & -23.8 & 71.4 & 9 & 566.44 \\
\hline 15.6 & -20.6 & 10.7 & -33.7 & -360.59 & 114.49 & $1,135.69$ \\
\hline-2.7 & -3.7 & -7.6 & -16.8 & 127.68 & 57.76 & 282.24 \\
\hline-2.8 & -3.8 & -7.7 & -16 & 123.2 & 59.29 & 256 \\
\hline-2.9 & -12 & -7.8 & -25.1 & 195.78 & 60.84 & 630.01 \\
\hline 54 & -144.1 & 0.1 & -252.7 & -939.37 & 2151.97 & 7545.58 \\
\hline
\end{tabular}

$$
\begin{gathered}
u=\frac{0.1}{11}=0.09 v=\frac{-252.7}{11}=-22.9 \\
\sum u_{i} v_{i}-11 \mathrm{uv}=-939.37-(2.27)=-937.1 \\
\sum U_{i}^{2}-11 \mathrm{u}^{2}=2,151.97-0.001=2,151.97 \\
\sum V_{i}^{2}-11 \mathrm{v}^{2}=7,545.58-5,768.51=1,777.07 \\
\mathrm{r}=\frac{-937.1}{\sqrt{(2,151.97 \times 1,777.07)}} \\
\mathrm{r}=-0.48 \text { (approx.) }-0.5
\end{gathered}
$$

The correlation coefficient is -0.5

Regression Analysis

$$
\begin{gathered}
Y=a+b x \\
\sum x=54, \sum y=-144.1, \sum x y=(1,782.49), \\
\sum x^{2}=2,417.06, \sum y^{2}=2,818.59
\end{gathered}
$$




$$
\begin{gathered}
\mathrm{a}=\frac{\left(\sum y\right)\left(\sum \mathrm{x}^{2}\right)-\left(\sum \mathrm{x}\right)\left(\sum \mathrm{xy}\right)}{n\left(\sum \mathrm{x}^{2}\right)-\left(\sum \mathrm{x}\right)^{2}}=\frac{(-144.1)(2,417.06)-(54)(1,782.49)}{11(2,417.06)-(54)^{2}}=\frac{(-444.552 .81)}{23,671.66}=-18.78 \\
\mathrm{~b}=\frac{n\left(\sum \mathrm{x} y\right)-\left(\sum \mathrm{x}\right)\left(\sum \mathrm{xy}\right)}{n\left(\sum \mathrm{x}^{2}\right)-\left(\sum \mathrm{x}\right)^{2}}=\frac{11(1,782.49)-(54)(-144.1)}{11(2,417.06)-(54 .)^{2}}=\frac{(-11,825.99)}{23,671.66}=-0.5
\end{gathered}
$$

Therefore, regression equation is: $y=-0.5 x-18.78$

Standard Deviation of the interest rates

$$
\frac{\sqrt{2151.97}}{11}=\sqrt{195.63}=14.0
$$

Mean \pm Std. Deviation $=4.9 \pm 14.0=18.9,-9.1$

$72.73 \%$ of the interest rates fall within the Mean \pm Std. Deviation range.

Mean \pm 2 x Std. Deviation $=4.9 \pm 28=32.9,-23.1$

$91 \%$ of the interest rates data fall within the Mean \pm 2 Std. Deviation range.

This implies that the standard deviation for the data distribution is low. The data distribution is therefore normal.

Standard deviation of the exchange rate

$$
\frac{\sqrt{7547.58}}{11}=\sqrt{1685.96}=26.2
$$

Mean \pm Std. Deviation=13.1 $\pm 26.20=39.3,-13.1$

$54.55 \%$ of the exchange rates fall within the Mean \pm Std. Deviation range

Mean \pm 2 x Std. Deviation $=13.1 \pm 52.4=65.5,-39.3$

$100 \%$ of the exchange rates fall within the Mean \pm 2 Std. Deviation range.

\section{Conclusion}

The results of the research indicate that increase in interest rate in Ghana results in fall in the country's exchange rate. High interest rates in Ghana therefore, negatively impacts the exchange rate. This finding defeats postulates that indicate that high interest rates result in high exchange rates. This situation in Ghana can be attributed to the fact that although high interest rate should induce persons to procure the country's currency, therefore, increasing demand for the currency, hence resulting in increase in the value of the currency, in Ghana the gap between the lending rates and the deposit rates is huge. Although, the country's lending rate increases, the corresponding increase in the deposit rate is low. For example, while the lending rate of a commercial bank in Ghana is $34 \%$ its deposit rate is $8 \%$ and considering the level of inflation in the country, it is not attractive to invest one's money for such low return on investment, hence an increase in interest rates in Ghana does not result in increase in the country's exchange rates but rather a fall in the exchange rate. Due to the relatively low interest rates on deposits in Ghana, people rather invest in assets that appreciate in value such as landed properties instead of lodging their funds in the banks when there is increase in interest rates which of course is not commensurate with the rate of inflation in the country; thus increase in interest rates in Ghana negatively impacts the exchange rate.

It is recommended that, for the country's interest rates to positively impact its exchange rates, the commercial banks should pay realistic and favorable interest rates to depositors when the lending rates increase. This will attract investors to bring foreign currencies into the country to procure the cedi and keep it with the banks, hence increase in demand for the cedi will result in increase in the value of the cedi. This will give Ghana better exchange rate.

Ghana should as well boost its exports by realistically promoting exports not only rhetorically but practically and must be seen to be achieving results so that the country's exchange rates can be favorable for economic planning purposes and improvement in the livelihood of its people.

\section{References}

[1] Walstand, W. B and Bingham, R. C (1993). Macroeconomics, twelfth edition, McGraw-Hill, Inc.

[2] Gordon, R. J (2006) Macroeconomics. Tenth edition, Pearson Addison Wesley.

[3] Eachern, W. A (2009). Principles of Macroeconomics, 41tr Press. Cengage.

[4] Abel, A. B and Bernanke, B. S (1995). Macroeconomics. Second edition, Addison-Wesley Publishing Company.

[5] Taylor, Alan, M., and Mark P. Taylor (2004). "The Purchasing Power Parity Debate." Journal of Economic Perspectives, vol. 18 (4): 135-158.

[6] Kargbo, J. M (2006). Purchasing Power Parity and exchange rate behaviour in Africa. Applied Financial Economics vol. 16 issue 1-2 pp 169-183.

[7] Suluk S and Tannseven K (2018). International Journal of Economics and Financial Issues | Vol 8 Issue 2 pg 372.

[8] Stafford, A. D (1995). Introduction to economics. Glencoe McGraw-Hill.

[9] Hubbard R. G and O'brien A. P (2009) Macroeconomics. Second edition, Pearson Prentice Hall.

[10] Khan R. S. A (2014) IOSR Journal of Business and Management (IOSR-JBM) e-ISSN: 2278-487X, p-ISSN: 2319-7668. Volume 16, Issue 6. Ver. II (Jun. 2014), p 116.

[11] Tumwine S, Sejjaaka S, Bbaale E, Kamukama N (2018) Determinants of interest rate in emerging markets A study of banking financial institutions in Uganda,. World Journal of Entrepreneurship, management and Sustainable Development, vol 2, p 1.

[12] Kartal M. T (2020) Determining Affecting Macroeconomic Indicators on Interest Rates in Emerging Countries: A Comparative Examination upon China, Brazil, and Turkey with Multivariate Adaptive Regression Splines (MARS), Journal of Empirical Economics and Social Sciences, vol 2, issue $1, \mathrm{p} 36$.

[13] Economic Affairs Series (1999). ECON 116 EN, (PE 168.283). 
[14] Kanwal K, Abbasi M. A, Burney A. I, Mubin M (2014) Journal of Economics and Sustainable Development www.iiste.orgISSN 2222-1700 (Paper) ISSN 2222-2855 (Online) Vol. 5, No. 13, 2014 p25.

[15] Association of Chartered Certified Accountants. (2000) Financial Strategy, BPP Publishers.
[16] Almani, A (2016), Accounting and Business magazine of ACCA. October 2016 edition, pg. 21.

[17] Ghana Statistical Service publications, 2019.

[18] Bank of Ghana publication, 2020. 